\title{
The Relationship between Key Entrepreneurial Traits and Venture Uncertainty and Success
}

\author{
Rizwana Bano Abdul Sattar Sheikh ${ }^{1}$, Dr J N Chakravorty ${ }^{2}$ \\ ${ }^{1}$ Research Scholar, LKMIMSR, Chandrapur, Gondwana University, Gadchiroli \\ ${ }^{2}$ Principal, Sau. Leena Kishor Mamidwar Institute of Management Studies \& Research, Kosara, Chandrapur
}

\begin{abstract}
The owner-human manager's capital is crucial to the success of small businesses. Entrepreneurial success is influenced by a number of things. Many authors and researchers believe that an entrepreneur's success is substantially determined by his or her personality traits, but they disagree on the relative value of particular traits. With entrepreneurship's growing social value and the number of entrepreneurial endeavours on the rise, it's only natural to wonder what distinguishes successful entrepreneurs from the others. Entrepreneurial success has been viewed as a multifaceted construct comprised of micro and macro aspects. Personality differences between entrepreneurs, nonfounder CEOs/leaders, and inventor workers have gotten little study, particularly in collaborative environments. While entrepreneurship is one of the most researched issues in business, results on the characteristics of entrepreneurs have been mixed. From a macro cross-cultural and cultural perspective to a meso occupational perspective to a micro individual behavioural standpoint, the current study looked at entrepreneurs' personal attributes.
\end{abstract}

Keywords: Entrepreneur, Entrepreneurial, Cultural Perspective, Behavioral Perspective

\section{Introduction}

The term "entrepreneurs" Individuals who take on new, innovative, and creative projects are sometimes referred to as innovators. According to research on the entrepreneurial personality, the majority of successful entrepreneurs have a set of personality qualities. Many different types of people play essential and varied roles in new companies. Entrepreneurs are required to challenge the current quo and lay the groundwork and generate the necessary energy for a new solution to a client need, industry structure, or business function. Non-founder CEOs and leaders assist in the development of business processes, operational capabilities, and organisational structures that enable new ideas to scale to commercial success. Employees who work as inventors develop new technology capabilities that are at the heart of high-growth businesses. Many other people work in areas ranging from sales and marketing to customer service and administrative support.

While each of these individuals plays an important role in innovation and economic success as entrepreneurs, non-founding CEO / leaders, employee inventors, and employees non-inventors, little is known about their personality traits. This is especially true when it comes to isolating companies and creative environments with all roles present and thus controlling confusing environmental influences. Understanding these distinctions can help with startup teams and can also help identify potential career paths (for example, if startup employees seem to have personalities and risk tolerances that could increase their chances of becoming future founders). Numerous researchers from around the world have focused on the study of entrepreneurs and entrepreneurship, addressing the topic from various theoretical points of 
view, basic techniques and methodology. As a result, the idea that entrepreneurship is a complex and varied phenomenon has been recognized.

\section{Literature Review}

Simon et al (2007) "found no evidence to substantiate that entrepreneurs are more self-confident than non entrepreneurs and overconfidence is bad for success in business. Success as an entrepreneur is primarily determined by the individual's smartness".

According to Nandram S. \& Samsom S. (2007), "the main determinants of a successful entrepreneur are found to be- watchful to spot the opportunities, persuasive, goal oriented, self-confidence, creativity, and courage, trustworthy, ambitious, capacity for empathy, perseverance \& locus of control."

Papzan et al (2008) found that "there was a significant relationship between need for achievement, innovation, internal locus of control, marketing, and lack of bureaucracy and success of entrepreneurs."

Robbin and Judge (2009) examined that "entrepreneurs' personality traits to identify traits that have impact on business performance. Personality traits such as internal locus of control and ambiguity tolerance influenced the business success directly and the business process indirectly."

Noor H. et al (2009) found that "there was strong evidence of association between entrepreneurial competencies and business success in Malaysia."

Abdullah F. et al (2009) confirmed that "eight factors are vital to the success of entrepreneurs. In rank order of importance, these factors are advancement drive, achievement oriented, commitment, decision-making ability, managing risk, tenacity, networking, and optimism."

Elenurm and Alas (2009) in a study reported "that courage to risk, openness to new information, flexibility, creativity and determination were the features of successful entrepreneurs in Estonia."

David Z. and Edward B. (2011) found those "entrepreneurs personal characteristics, such as need for achievement, need for cognition and internal locus of control, have positive influences on firm performance."

\section{Venture Innovation}

Companies will gain a competitive advantage through acts of innovation. As a result, a causal relationship exists between a company's growth and profitability. The ability of a company to harness the creativity of its personnel in order to improve processes and products is characterised as its innovativeness. To instil a culture of innovation, successful entrepreneurs transmit their innovative features to the organisational DNA. According to a survey, the owner had a key role in the creation of innovations in 85 percent of the companies. Small and medium businesses (SME) can increase their ability to harness the creative talents of their employees by adopting the attributes of their founders. An entrepreneur's capacity to see an opportunity, as well as the self-efficacy to pursue it, is the source of innovation. Entrepreneurs start businesses to capitalise on an opportunity by bringing together a unique set of resources to provide better value than the status quo or meet a market need. Many entrepreneurial organisations are innovative because they have the capacity to "link the dots" and the conviction to follow through on their ideas. 


\section{Venture Growth}

Firms must develop to some level in order to compete in the marketplace. In entrepreneurship research, firm growth has become a significant gauge of success because it demonstrates the magnitude of benefit arising from entrepreneurial conduct. The discovered market opportunity and accompanying creative solution are validated by venture growth, reinforcing the initial success metric. There is, however, a causal relationship between an entrepreneur's growth motivation and the firm's growth. Entrepreneurs have a range of motivations for launching a business. The reasons for starting a business will have a significant impact on their desire to expand. Entrepreneurial development motivation is driven by the entrepreneur's desire for success, risk tolerance, and perception of opportunities. When examining essential characteristics that influence business growth, it is assumed that an innovative opportunity has been found and pursued. The amount to which an opportunity is scaled, or the expansion of a business, is determined by the entrepreneur's need for achievement and risk tolerance.

\section{A. New Ventures}

1. Characteristics of the Company: Information on new businesses includes details such as the sector in which they operate, when they started operating, the size of the team and the role of the entrepreneur in the new company. Furthermore, the initiatives were classified according to their level of uncertainty, determined by the two dimensions of novelty and technology of the Shenhar and Dvir framework, which are the most important for the management of a new company.

Each dimension is divided into three or four categories, which allow a more precise definition of the project (company) in question. Novelty refers to the size of the market and describes how new the new business idea is for its potential users (market). A revolutionary idea is totally new to the market; customers don't know what the new product is for or how to use it. On the other hand, there are derivative elements which are small improvements to an existing product and are easy for customers to adopt and use. The technological dimension refers to the level of technological uncertainty that exists when a new company starts producing a new product, or, in other words, what technologies the company will have to master to build the new product in a way that meets the requirements. customer needs. Low-tech startups have all the technologies needed for the new product in-house, while startups at the other end of the tech spectrum must develop entirely new technologies to match the functional capabilities of the new product. The degree of technological uncertainty varies according to the sector in which the new company operates; While a technology can be considered high-tech in one area, it can only be labeled medium-tech in a more developed area.

2. Type of Enterprise: according to the degree of innovation and technological uncertainty, the initiatives have been divided into three groups. Due to the small sample size and the number of retries, only three groups of the twelve possible combinations were chosen. In the first phase, six possible cells were excluded, as the sample did not contain innovative or ultra-technological products. In the second phase, three types of initiatives were identified based on the products made:

(a) Derivatives of low and medium technology (products or services that show only modest improvements compared to older products compared to the market and the level of technology used).

(b) Low to medium technology platform products (a new generation of products, with low to medium technological uncertainty).

(c) High-tech platform products (a new generation of high-tech products). 
3. Firm's Level of Uncertainty: The product of novelty (market uncertainty) and technology is used to determine the firm's general level of uncertainty (technological uncertainty). This combined measure includes market and technology uncertainty, both of which are related to business risk.

\section{B. Entrepreneurial Personality}

Fourteen traits found in previous research to characterize entrepreneurs (e.g., love of challenges, commitment, and especially risk-taking) (Alpha Cronbach of $14=.82$ ). The items were presented randomly and the entrepreneurs were asked to rate the degree to which each of these traits characterizes them on a 7point scale ranging from $1=$ not at all to $7=$ definitely yes.

\section{Business Success Criteria}

Business success was measured in three dimensions: efficiency (achievement of planning and budget objectives), business results (achievement of economic and marketing objectives) and creation of future opportunities (potential to create new markets and new business lines Products) .

\section{Results and Findings}

\begin{tabular}{|l|c|c|}
\hline Variable & Risk Taker & Venture Uncertainty \\
\hline Loves Challenges & $0.47^{* *}$ & $0.32^{* *}$ \\
\hline Committed & $0.29^{* *}$ & $0.24 * *$ \\
\hline Shows Initiative & $0.47^{* *}$ & $0.22^{* *}$ \\
\hline Independent & $0.31^{* *}$ & 0.11 \\
\hline Involved & $0.15^{*}$ & -0.02 \\
\hline Dreamer & $0.28^{* *}$ & 0.03 \\
\hline Optimistic & $0.46^{* *}$ & 0.13 \\
\hline Creative & $0.44^{* *}$ & 0.06 \\
\hline Persistent & -0.05 & $0.18^{* *}$ \\
\hline Rebellious & $0.43^{* *}$ & 0.05 \\
\hline Likes to manage & 0.02 & 0.07 \\
\hline Realistic & 0.05 & $0.17 *$ \\
\hline Needs control & -0.02 & 0.12 \\
\hline Energetic & $0.32^{* *}$ & $0.24 * *$ \\
\hline Self confident & $0.26^{* *}$ & 0.11 \\
\hline Investigative & $0.22^{* *}$ & $0.34 * *$ \\
\hline Novelty & -0.03 & $0.80 * *$ \\
\hline Technological uncertainty & $0.17^{*}$ & $0.87 * *$ \\
\hline Exceeded budget goal (reversed) & -0.11 & $-0.25 * *$ \\
\hline Exceeded schedule (reversed) & -0.08 & $-0.30 * *$ \\
\hline Met main business milestones & 0.07 & 0.11 \\
\hline Potential to enter a new market & $0.22^{* *}$ & $0.24 * *$ \\
\hline & & \\
\hline & & $* 3$ \\
\hline
\end{tabular}




\begin{tabular}{|l|c|c|}
\hline Potential to create a new product-line & $0.22^{* *}$ & $0.25^{* *}$ \\
\hline New technological infrastructure was created & -0.05 & $0.31^{* *}$ \\
\hline New operational infrastructure was created & 0.02 & $0.18^{*}$ \\
\hline New technological knowledge was accumulated & 0.12 & $0.22^{* *}$ \\
\hline Met economic goals set in the BP & $0.22^{* *}$ & 0.07 \\
\hline Product sold according to plan & -0.07 & 0.03 \\
\hline Market penetration goals met & 0.10 & $0.21 *$ \\
\hline Financial resources not exhausted & $-0.19^{*}$ & -0.01 \\
\hline Employees stayed throughout development & $0.20^{* *}$ & $0.15^{*}$ \\
\hline Overall success & 0.02 & $0.17 *$ \\
\hline Age & $-0.14 *$ & 0.02 \\
\hline Education & 0.03 & $0.17 *$ \\
\hline$* * \quad$ Significant at $5 \%$ & & \\
$* \quad$ Significant at $10 \%$ & & \\
\hline
\end{tabular}

Table 1: Correlations of Entrepreneurs' Traits and Success Measures With Risk-Taking Variable And With Uncertainty Variable (Market And Technology)

As we can see in Table 1, Entrepreneurs' willingness to take risks was found to be strongly linked to their love of challenges, initiative, optimism, creativity, energy, independence, commitment, being a dreamer, being confident, and being investigative. It had nothing to do with realism, the need for control, or a desire to manage. Risk-taking was also found to be linked to the venture's level of technological uncertainty, but not to novelty.

\begin{tabular}{|c|c|c|c|c|c|c|c|c|}
\hline \multirow[t]{2}{*}{ Traits and Measures } & \multicolumn{3}{|c|}{ Means by Group } & \multicolumn{3}{|c|}{$\begin{array}{c}\text { Mean Comparison by Pair } \\
\text { Sig. Level }\end{array}$} & \multicolumn{2}{|c|}{$\begin{array}{c}\text { F Test - All Three } \\
\text { Groups }\end{array}$} \\
\hline & & 2 & & "1-2" & "1-3" & "2-3" & $\mathbf{F}$ & Sig. \\
\hline Loves challenges & 5.42 & 6.21 & 6.44 & 0.011 & 0.001 & 0.427 & 6.508 & 0.002 \\
\hline Committed & 5.85 & 6.18 & 6.56 & 0.254 & 0.012 & 0.164 & 3.360 & 0.039 \\
\hline Shows Initiative & 6.19 & 6.29 & 6.59 & 0.679 & 0.069 & 0.155 & 1.933 & 0.151 \\
\hline Independent & 6.19 & 6.50 & 6.35 & 0.206 & 0.489 & 0.517 & 0.812 & 0.447 \\
\hline Involved & 5.92 & 5.96 & 5.91 & 0.894 & 0.970 & 0.857 & 0.017 & 0.983 \\
\hline Dreamer & 4.81 & 5.04 & 5.00 & 0.613 & 0.655 & 0.933 & 0.150 & 0.861 \\
\hline Optimistic & 5.31 & 5.50 & 5.85 & 0.618 & 0.141 & 0.329 & 1.168 & 0.316 \\
\hline Creative & 5.85 & 6.04 & 6.15 & 0.520 & 0.287 & 0.686 & 0.578 & 0.563 \\
\hline Persistent & 5.65 & 5.75 & 6.15 & 0.750 & 0.090 & 0.162 & 1.737 & 0.182 \\
\hline Rebellious & 4.81 & 4.68 & 4.94 & 0.777 & 0.759 & 0.539 & 0.191 & 0.826 \\
\hline Risk taker & 5.04 & 5.07 & 5.29 & 0.924 & 0.440 & 0.492 & 0.376 & 0.688 \\
\hline Likes to manage & 5.00 & 5.07 & 5.47 & 0.858 & 0.218 & 0.286 & 0.940 & 0.394 \\
\hline Realistic & 5.50 & 5.57 & 6.00 & 0.813 & 0.085 & 0.131 & 1.868 & 0.161 \\
\hline Needs control & 4.81 & 4.89 & 5.24 & 0.845 & 0.305 & 0.401 & 0.626 & 0.537 \\
\hline Energetic & 5.27 & 5.57 & 5.94 & 0.318 & 0.022 & 0.193 & 2.770 & 0.068 \\
\hline
\end{tabular}




\begin{tabular}{|llll|lll|ll|}
\hline Self confident & 5.54 & 5.96 & 5.85 & 0.097 & 0.198 & 0.641 & 1.515 & 0.226 \\
Investigative & 2.04 & 2.46 & 3.24 & 0.217 & 0.000 & 0.018 & 7.077 & 0.001 \\
\hline Novelty & 1.00 & 1.86 & 2.00 & 0.000 & 0.000 & 0.007 & 202.60 & 0.000 \\
Tech uncertainty & 1.62 & 1.96 & 3.00 & 0.003 & 0.000 & 0.000 & 89.594 & 0.000 \\
\hline Met budget goal & 5.58 & 5.61 & 4.40 & 0.962 & 0.019 & 0.018 & 4.063 & 0.021 \\
Met schedule goal & 5.12 & 4.65 & 3.72 & 0.369 & 0.006 & 0.068 & 4.272 & 0.018 \\
Met main business milestones & 4.88 & 5.00 & 5.36 & 0.787 & 0.272 & 0.419 & 0.661 & 0.519 \\
Potential for new market & 4.43 & 4.73 & 5.69 & 0.632 & 0.034 & 0.099 & 2.684 & 0.075 \\
Potential for new product line & 4.41 & 4.82 & 5.72 & 0.506 & 0.023 & 0.114 & 2.966 & 0.058 \\
New technology created & 3.45 & 4.36 & 5.39 & 0.166 & 0.002 & 0.092 & 5.020 & 0.009 \\
New operational infrastructure & 3.70 & 4.65 & 4.74 & 0.121 & 0.070 & 0.873 & 1.940 & 0.152 \\
New knowledge & 4.55 & 5.30 & 5.81 & 0.169 & 0.016 & 0.323 & 3.047 & 0.054 \\
Economic goals & 4.92 & 5.24 & 5.15 & 0.509 & 0.612 & 0.849 & 0.242 & 0.786 \\
Met marketing goals & 5.19 & 4.75 & 4.95 & 0.461 & 0.669 & 0.746 & 0.281 & 0.756 \\
Met penetration plan & 5.00 & 4.56 & 5.47 & 0.414 & 0.354 & 0.106 & 1.361 & 0.265 \\
Did not exceed financial resources & 5.15 & 5.00 & 4.90 & 0.795 & 0.636 & 0.858 & 0.113 & 0.893 \\
Retained HR & 4.60 & 5.62 & 5.39 & 0.059 & 0.126 & 0.652 & 2.026 & 0.139 \\
\hline
\end{tabular}

Table 2: Personal Traits, Levels of Uncertainty and Venture Success By Venture Types

Table 2 shows that some of the character traits identified to be substantially correlated with risk-taking (love of challenges, proclivity to take initiative, energy, dedication, confidence, and investigativeness) are also associated with new enterprises that are more risky (type 3 ventures). Another intriguing discovery is that these high-risk ventures are more successful in generating future opportunities. Ventures associated with lower levels of risk (type 1 and type 2), on the other hand, have higher levels of efficiency (meeting schedule and budget goals).

\section{Conclusion}

The value and importance of interdisciplinary studies combining a psychological perspective with an economic and management perspective speak to the value and importance of interdisciplinary studies combining a psychological perspective with an economic and management perspective. This multidisciplinary approach is in stark contrast to the mainstream of entrepreneurial research, which tends to draw on a variety of theoretical viewpoints and basic concepts, as well as a variety of methodologies, often yielding contradictory results.

\section{References}

[1] Nandram S. \& Karel Samsom (2007), Entrepreneurial Behaviour, NRG Working Paper no. 07-04.

[2] Simeon Djankov et al (2007), What Makes a Successful Entrepreneur? Evidence from Brazil.

[3] Papzan et al (2008), Determining factors influencing rural entrepreneurs' success, African Journal of Agricultural Research Vol. 3 (9), pp. 597-600.

[4] Robbins, S.P. and Judge, T.A. (2009), Organizational Behaviour. Pearson education, New York.

[5] Noor H. et al (2009), Is entrepreneurial competency and business success relationship contingent upon business environment? A study of Malaysian SMEs, International Journal of Entrepreneurial Behaviour \& Research, Vol. 16 No. 3, 2010, pp. 182-203 
[6] Abdullah F. et al (2009), Developing a framework of success of Bumiputera entrepreneurs, Journal of Enterprising Communities, Vol. 3 No. 1, 2009 pp. 8-24

[7] David Z. and Edward B. (2011), Personal characteristics and strategic orientation: entrepreneurs in Canadian manufacturing companies, International Journal of Entrepreneurial Behaviour \& Research, Vol. 17 No. 1, 2011, pp. 82-103 